\title{
Further Observations on the Fungus present in Pellia epiphylla, (L.) Corda.
}

BY

\author{
W. F. F. RIDLER, M.Sc. \\ With three Figures in the Text.
}

$7 \mathrm{HE}$ distribution, isolation, identification, and physiological relationship to its host of the fungus present in Pellia epiphylla have been described

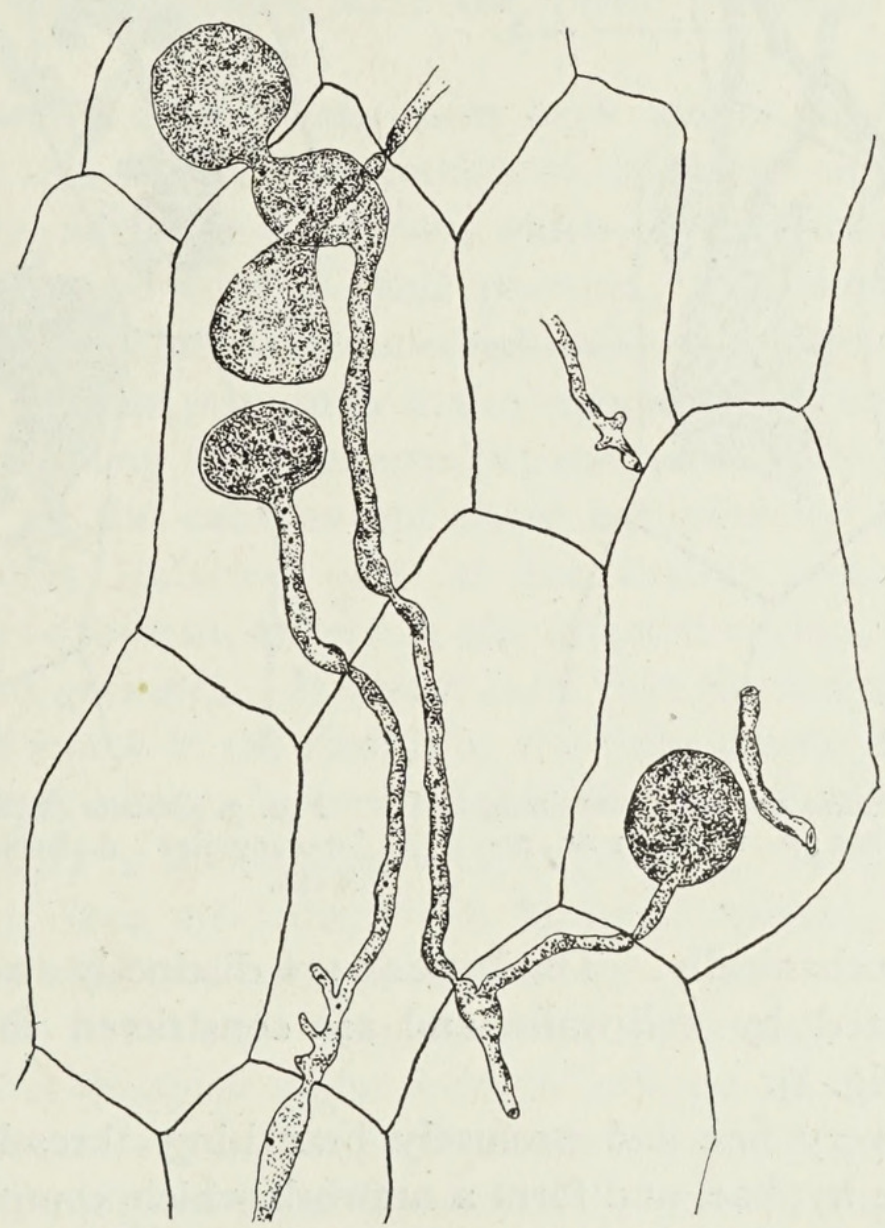

FIG. I. Cells of Pellia epiphylla with hyphae and vesicles, indicating method of penetration of the cell-walls. $\times 290$.

in a previous paper (Ridler, 1922). Some additional observations are recorded here.

Behaviour of the fungus in cells of the thallus. By reason of its lightbrownish colour, the zone of cells occupied by the fungus in the thallus of

[A nnals of Botany, Vol. XXXVII. No. CXLVII. July, 1923.] 
the liverwort can be recognized in sections of fresh material examined with a low power magnification ( $x$ I00), but individual hyphae cannot be so distinguished. Under a higher magnification $(x 440)$ numerous relatively large hyphae are visible. These branch profusely, passing from cell to cell by piercing the cell-walls. Except at the points of penetration no injuries to the cell-walls, owing to the passage of the hyphae, have been detected, nor have any traces of the presence of an enzyme causing the destruction of the cell-wall been observed. Penetration of the cell-walls seems, therefore

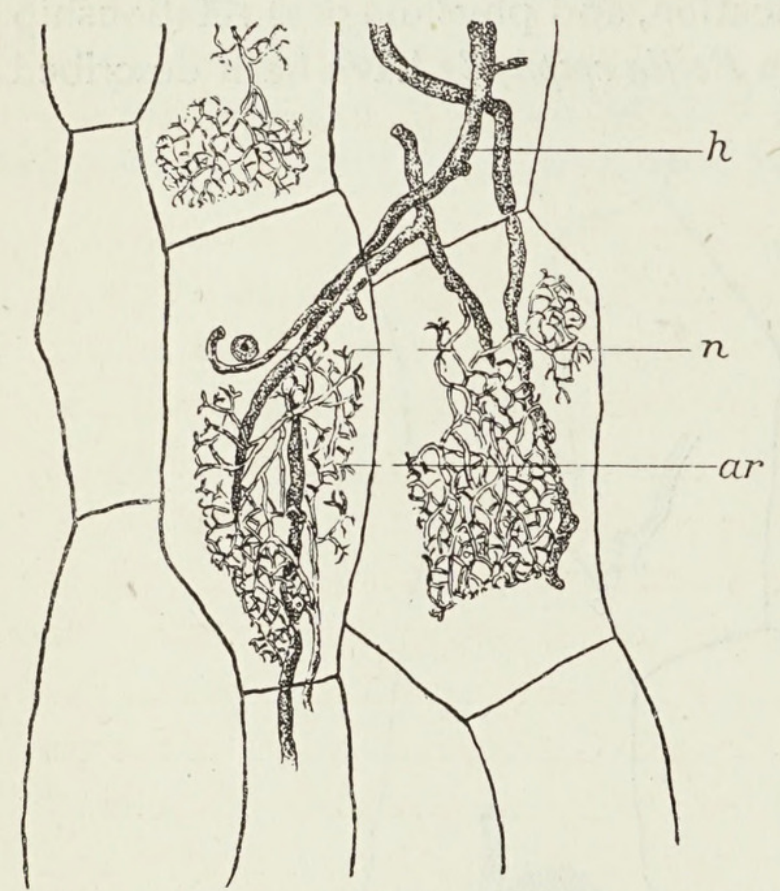

Fig. 2. Cells of Pellia epiphylla containing ' arbuscules'. h., hyphae ; n., nucleus ; ar., arbuscules. $\times 290$.

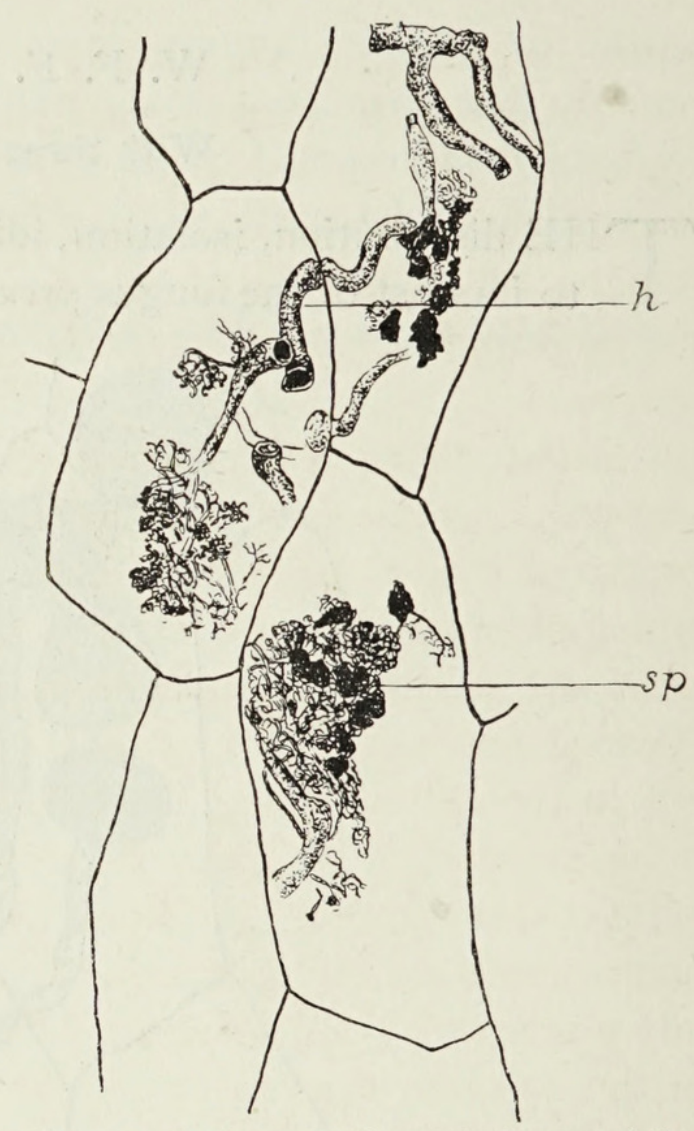

Fig. 3. Cells of Pellia epiphylla containing 'sporangioles'. h., hyphae; sp., sporangioles. $\times 290$.

to be effected mechanically. The hyphae are distinctly swollen where their growth is arrested by cell-walls, and are constricted for their passage through them (Fig. I).

Numerous very fine and profusely branching threads are produced from some of the hyphae, and form a network which completely fills some of the cells (Fig. 2). These threads, which can be made more conspicuous by staining with picro-nigrosine, probably correspond to the 'arbuscules' described by Noel Bernard (1911) in Solanum Dulcamara, and by J. Magrou (1921) in Solannm tuberosum, Orobus tuberosus, and Mercurialis perennis. These 'arbuscules' degenerate later into irregular masses termed by Bernard 'sporangioles' (Fig. 3). These masses are insoluble in water, alcohol, henzol, chloroform, and other similar solvents, also in the 
common acids, whether in the cold or when heated. In the presence of iodine, hyphae, 'arbuscules', and 'sporangioles' turn yellow in colour, and with chlor-zinc-iodine they become a reddish brown. The mycosin test for chitin described by Wisselingh (1898) was tried, and after this treatment the 'sporangioles', the walls of the hyphae, and the 'arbuscules' all stained a reddish violet with chlor-zinc-iodine, while the cell-walls of the liverwort turned blue; a similar result was obtained with iodine and a trace of sulphuric acid. The main hyphae continue to ramify in the thallus, but the liverwort seems to possess some sort of control over the fungus, the nature of which is not exactly known, by which the latter is prevented from obtaining too great a hold on the plant and from becoming harmfully parasitic. The 'arbuscules' are not capable of passing from cell to cell, so that by their formation the growth of the fungus is restricted. Noel Bernard (1909) compared the condition of such a plant to that of a vaccinated animal, and suggested that the plant possessed une immunité humorale.

Although careful observations have been made, no differences have been noted in the size, shape, or structures of the nuclei in infected cells as compared with the nuclei of cells from which the fungus is absent. The only difference observed was in their position. In uninfected cells the nuclei are peripheral, whereas in infected cells they are more often in a central position in close proximity to the 'sporangioles' and 'arbuscules'.

In the case of young thalli infected at one point only, starch is found to be present in all the cells except those occupied by the fungus. In 'rejuvenation shoots' infected only at the thallus end, a considerable quantity of starch is present, except in the infected region, where there are only a few isolated granules. It would seem that the fungus is responsible for the absence of starch in the thallus of the fully developed gametophyte of Pellia. There is always a considerable amount of oil in the infected region, and especially in the swollen vesicles (Fig. I). As a rule no reaction is obtained when these are tested with Millon's reagent, though in one instance a definite brick-red coloration resulted.

Culture of the liverwort. The constant occurrence of the fungus in the thallus of Pellia epiphylla might seem to indicate an obligate symbiosis between the two organisms. Attempts made in $192 \mathrm{I}$ to grow Pellia plants from young gametophytes were unsuccessful; growth began, a few celldivisions took place, and one or two rhizoids were produced, but growth did not proceed farther. Attempts were made again in the spring of 1922 when the capsules were mature. The medium employed was a modification of Knop's solution as used by Servettaz (1913) in his experiments on mosses. The cultures were made under sterile conditions in Petri dishes, at the bottom of which several rounds of filter-paper were placed. A capsule of Pellia was immersed in a one per cent. mercuric chloride solution 
for a few seconds, washed in sterilized distilled water, burst with a sterilized needle, and removed by means of the latter to a Petri dish, where its contents were rubbed over the surface of the filter-paper, the young gametophytes being thus distributed. The dishes were supplied periodically with fresh medium, so that the filter-paper was kept damp. The cultures were placed in a north window, so that adequate light was obtained without direct sunlight. Growth began almost immediately and continued, but, owing to overcrowding, the thalli produced were somewhat attenuated, but otherwise quite healthy.

Isolation and inoculation of the fungus. Further attempts were made to isolate the fungus from the thallus, but, as before, these were unsuccessful. Bernard and Magrou found similar difficulty in isolating the endophytes described by them in species of Solanum, and suggested that the 'arbuscules' are more adapted to a parasitic life than the 'pelotons' formed by the endophytes of the majority of the orchids, and are incapable of developing in the autophytic state.

Attempts were also made to re-inoculate the fungus isolated from the sporophyte into uninfected Pellia plants obtained in the manner described above, but these were also unsuccessful. Confirmation that the fungus previously isolated is the true endophyte of Pellia is therefore still lacking.

Observations on the hydrogen-ion concentration. Soil on which Pellia epiphylla was growing was obtained from Leigh Woods, Somerset, and its hydrogen-ion concentration was measured colorimetrically. Two methods were used for obtaining the soil solution-the centrifuge method described by Gillespie and Hurst (1917), and the displacement method first described by Gola (I9IO) and quoted in a paper by Cavers (1914) on 'Gola's Osmotic Theory of Edaphism'. The figures obtained from these solutions were as follows :

\section{Soil solution obtained by \\ Centrifuge method Displacement method}

Indicator.

Phenol red Phenol red

$$
\begin{gathered}
\text { pH Value. } \\
6.8-7.0 \\
6.8-7 \cdot 0
\end{gathered}
$$

\section{Summary.}

I. The growth and consequent distribution of the fungus in the thallus of Pellia epiphylla is restricted, as shown by the formation of 'arbuscules' and 'sporangioles'. Some sort of control is thus exerted by the liverwort, and the fungus is prevented from becoming harmfully parasitic.

2. The fungus undoubtedly obtains food material from the cells of the liverwort, in the form of starch which is replaced by oil after the entrance of the fungus. It is very doubtful whether the liverwort gains anything by the association. It is possible that nutrient substances may be absorbed by the fungus from the substratum, as Stahl (1900) suggests, but the con- 
siderable quantity of starch present in the thallus before the action of the fungus does not support this view.

3. The $\mathrm{pH}$ value of soil upon which Pellia was growing was found to be slightly acid.

4. Notwithstanding the constant occurrence of the fungus in the liverwort, symbiosis is not obligate, as plants of the liverwort have been grown without the fungus.

My thanks are due to Mr. C. T. Gimingham for information regarding the displacement method of obtaining soil solutions; to Mr. C. Hunter for much valuable help and advice; and to Professor O. V. Darbishire for his interest in the work.

During the progress of this investigation I have been in the receipt of a maintenance grant from the Department of Scientific and Industrial Research.

\author{
Cryptogamic Research Laboratory, \\ UNIVERSITY OF BRISTOL, \\ November i9a2.
}

\title{
REFERENCES.
}

1. Bernard, N.: L'Évolution dans la Symbiose. Ann. des Sci. Nat., Bot., $9^{e}$ série, ix, 1909, p. I.

2. $:$ Les Mycorhizes des Solanum. Ibid., $9^{\text {e }}$ série, xiv, r9I I, p. 235.

3. Cavers, F. : Gola's Osmotic Theory of Edaphism. Journal of Ecology, vol. ii, I9I4, p. $20 \mathrm{~g}$.

4. Gillespie, L. J., and Hurst, L. A.: Hydrogen-ion Concentration Measurements of Soils of two Types: Caribou Loam and Washburn Loam. Soil Science, vol. iv, I9I7, p. 3II.

5. Magrou, J. : Symbiose et Tubérisation. Ann. des Sci. Nat., Bot., I0 ${ }^{e}$ série, iii, I92 I, p. I8I.

6. Ridler, W. F. F.: The Fungus present in Pellia epiphylla. Ann. of Bot., vol. xxxvi, I922, p. I93.

7. Servettaz, C.: Développement et la nutrition des Mousses en milieux stérilisés. Ann. des Sci. Nat., Bot., $9^{\mathrm{e}}$ série, xvii, I913, p. III.

8. Stahl, E. : Der Sinn der Mycorhizenbildung. Jahrb. für wissenschaft. Bot., xxxiv, 1900, p. 539 .

9. Wisselingh, C. VAN: Mikrochemische Untersuchungen über die Zellwände der Fungi. Ibid., xxxi, I898, p. 6r 9 . 


\section{$2 \mathrm{BHL}$ Biodiversity Heritage Library}

Ridler, W. F. F. 1923. "Further observations on the fungus present in Pellia epiphylla, (L.) corda." Annals of botany 37, 483-487. https://doi.org/10.1093/oxfordjournals.aob.a089860.

View This Item Online: https://www.biodiversitylibrary.org/item/270686

DOI: https://doi.org/10.1093/oxfordjournals.aob.a089860

Permalink: https://www.biodiversitylibrary.org/partpdf/319097

\section{Holding Institution}

New York Botanical Garden, LuEsther T. Mertz Library

\section{Sponsored by}

BHL-SIL-FEDLINK

\section{Copyright \& Reuse}

Copyright Status: Public domain. The BHL considers that this work is no longer under copyright protection.

This document was created from content at the Biodiversity Heritage Library, the world's largest open access digital library for biodiversity literature and archives. Visit BHL at https://www.biodiversitylibrary.org. 